\title{
Analysis of Non-fund Based Financial Services: Some Insights from India
}

\author{
Gursharan Singh Kainth (Corresponding author) \\ Guru Arjan Dev Institute of Development Studies \\ 14-Preet Avenue,Majitha Road, PO Naushera, Amritsar-143008, India \\ Tel: +91-183-2426045Ｅ-mail: idsasr@gmail.com
}

Received: December 18, $2010 \quad$ Accepted: February 15, $2011 \quad$ doi:10.5430/rwe.v2n1p98

\begin{abstract}
Merchant banking services strengthen the economic development of a country as they acts as sources of funds and information for corporations. Considering the way the Indian economy is growing, the role of merchant banking services in India is indispensable. These financial institutes also act as corporate advisory bodies to help corporations rightly get involved in various financial activities. The need of merchant banking services in India arises from the fact that high level industrialization is taking place in the country. Some of the PSBs have formed their fully owned subsidiaries for this purpose. Analysis of merchant banking business of some PSBs clearly indicates that the merchant banking activities of the banks are showing declining trend especially after 1993-94 due to depressed capital market conditions and subdued activity in primary market.
\end{abstract}

Keywords: Merchant banking, Public sector banks, Financial services

\section{Introduction}

Financial Liberalization has highlighted competition among banks and other financial institutions. As a result, public sector banks have not only diversified their fund based financial services, e.g. mutual funds, factoring, forfeiting etc. but also their non fund based financial services. This would help them to increase their revenue while optimizing the use of funds and would help to spread their risk over variety of activities. The non fund based financial services of the public sector banks include loan syndication, consultancy and advisory services, capital issue management etc. The public sector banks have been marketing all the non fund based financial services either directly by starting merchant banking division or by indirectly floating their subsidiary companies or both. This paper emphasis on the analysis of non fund based financial services of public sector banks in India.

\subsection{Merchant Banking}

Non-fund based financial services of the public sector banks are covered under merchant banking activities. Merchant banking services has been statutorily brought under the regulatory frame work of the Securities and Exchange Board of India (SEBI) under the SEBI Act 1992. No person can act as a merchant banker without obtaining a Certificate of Registration from SEBI. According to SEBI, a merchant banker is a person who is engaged in the business of issue management either by making arrangement regarding selling, buying or subscribing to securities as a manager, consultant, advisor or rendering corporate advisory services in relation to such issue management. Considering the approach the Indian manage to buy is growing, the role of merchant banking services in India is indispensable. These financial institutes additionally act as corporate advisory bodies to great corporations righteously get endangered in assorted financial activities. The need of merchant banking services in India arises from the tall turn automation that is receiving place in the country. Hence there is need for learned professionals who can take caring of assorted finance-related needs of the modernized industrial sectors. These dilettante services have been additionally of great significance for the tiny as good as to middle sized enterprises to great them work smoothly. Most of the farming areas still miss industrial enrichment as good as the categorical reasons for this embody miss of supports as good as information. The merchant banking services great the entrepreneurs to come up with industrial setups in these areas. Besides, the businessman banks great the entrepreneurs to try opportunities in the unfamiliar markets. The upon tip of contention highlights the ways businessman banks have been compelling industrial growth in India. The supervision in the nation plays the poignant role by arising manners as good as regulations for businessman banks so that entrepreneurs can have most out of these services. 


\subsection{Evolution of Merchant Banking}

The origin of merchant banking traced to Italy in the mid fifteenth and France during the seventeenth and eighteenth centuries. Cosimo De Medier, an Italian Merchant Bbanker established net work of operations beyond Italy with offices in London, Belgium and France. The Italian merchant banker introduced into England all the institutions and techniques connected with an organized money market. In France a merchant banker added banking business to his merchant activities. In the United Kingdom merchant banks came into existence in the late eighteenth century. Merchant banks initially included acceptance houses, discount houses and issue houses. They used to finance sovereign government through grant of long term loan. Since the end of Second World War, commercial banks in Western Europe have been offering multiple services including merchant banking services. After the great crash of 1929 and depression, the investment banking was separated from commercial banking under the Glass-Steagall Banking Act-1933. Investment trusts were covered by Investment Company Act 1940.

\subsection{Growth of Merchant Banking in India}

Merchant Banking as a commercial activity took place in India through the management of Public Issues of Capital and Loan Syndication. It was originated in 1969 with the setting up of the Merchant Banking Division of ANZ Grind lays Bank. The main service offered at that time to the corporate enterprises by the merchant banks included the management of public issues and some aspects of financial consultancy. The early and mid seventies witnessed a boom in the growth of merchant banking organizations in the country with various commercial banks, financial institutions, broker's firms entering into the field of merchant banking.

$<$ Figure 1 about here $>$

In 1970 Citi bank set up its merchant banking division with the objectives of assisting new entrepreneurs and existing units in the evaluation of new projects and raising funds through borrowing and issue of equity. In pursuance to the recommendation of the Banking Commission-1972, Indian bank started merchant banking services. State Bank of India started the merchant banking division in 1972. The Foreign Exchange Regulation Act-1973 necessitated dilution of foreign equity of large number of foreign companies operating in India. As a result, large number of investors was created in capital market and merchant banking become attractive to banks and the firms of consultants.

In 1974 ICICI also initiated the merchant banking services The commercial banks that followed SBI were: Central Bank of India; Bank of India and Syndicate Bank in 1977; Bank of Baroda, Standard Chartered Bank and Mercantile Bank in 1978; United Bank of India, United Commercial Bank, Punjab National Bank, Canara Bank and Indian Overseas Bank in late 70's and early 80's. The financial institutions that followed ICICI in starting merchant banking activities are: IFCI (1986) and IDBI (1991). After mid seventies, there was a boom in the growth of merchant banking organization in the country. SBI, Canara Bank, Bank of Baroda and Punjab National Bank have floated wholly owned subsidiaries, namely, SBI Capital market Ltd;(SBICAP); Canbank Financial Services ltd.(CANFINA); Bank of Baroda Fiscal Services Ltd.(BOB Fiscal) and PNB Capital Services Ltd.

Financial and technical Consultants and professionals also entered in merchant banking business. Currently, most of the foreign banks are offering these services. They have been active in the area of arranging and syndicating foreign currency loans and in attracting foreign investment in India. They have also been providing advisory services and other type of assistance to foreign companies desiring to set up joint ventures in India.

\section{Regulating Framework of Merchant Banking:}

Merchant banking activities were regulated by

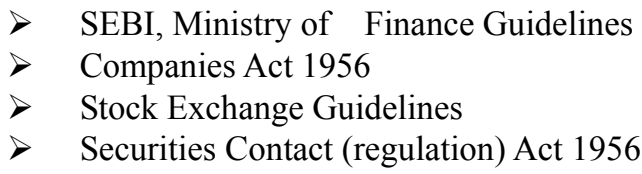

Now merchant banking has been statutorily brought under the regulatory framework of the Securities and Exchange Board of India (SEBI) Act 1952. No person can act as a merchant banker without the obtaining a Certificate of Registration from SEBI. Merchant banking activities are being organized and undertaken in several forms. Commercial banks both Indian and foreign and Development Finance Institutions(DFIs) have organized them through formation of Divisions; nationalized banks through forming subsidiary companies and share brokers and consultancies constituted themselves into public limited companies or registered themselves as a private limited companies or firms, partnership or proprietary concerns. Merchant bankers, irrespective of the form in which they are organized are governed by the Merchant Bankers Rules issued by the Ministry of Finance and Merchant Banking Regulation issued by SEBI on December 22, 1992. 
The authorized activities of the merchant bankers included (a) issue of management which consist of preparation of prospectus and other information relating to the issue, determining financing structure, tie up of financers and final allotment and/or refund of subscription; (b) corporate adviser services relating to the issue;(c) underwriting; (d) portfolio management services, and (e) managers consultants or advisors in the issues.

All merchant bankers are expected to perform with high standards of integrity and fairness in all their dealings. A Code of Conduct has been prescribed for merchant bankers by SEBI. Within this context the criteria for a Certificate of Registration take into account;

$>$ Professional competence

$>$ personnel, their adequacy and quality and other infrastructure

$>$ Capital adequacy; and

$>$ Past track record experience, general reputation and fairness in all their transactions.

Up to August 1997, the regulation of the SEBI Act provided for registration under four categories of merchant bankers:

Category-I can act as an issue manager, advisor consultant, under writer and portfolio manager with minimum resources up to Rs five crores

Category-II can act as an advisor, consultant, co-manager underwriter and portfolio manager with minimum resources up to Rs fifty lakhs

Category-III can act as underwriter and portfolio manager with minimum resources up to Rs twenty five lakhs

Category- $I V$ can act only as an advisor or consultant to an issue with no minimum resources.

All issues should be managed by at least by one authorized merchant bankers, functioning as the sole manager or lead manager. Every merchant banker is required under the regulation to abide by the code of conduct. Accordingly every merchant banker is required to act in an ethical manner, render high standard of service and exercise due diligence, not to indulge in unfair practices, not to divulge confidential information about the client, endeavour to ensure that true and adequate information is provided to investors. Merchant banker is required to maintain and keep a copy of the balance sheet, a copy of auditor's report and a statement of financial position and to furnish annually the final accounts and such other documents to SEBI as well as half yearly working results. Merchant banker is required to enter into agreement with a corporate body setting out their mutual rights, liabilities and obligations relating to such issue.

A lead manager should furnish to SEBI a statement specifying disclosed responsibilities relating to issue. It is the duty of lead manager to verify the contents of a prospectus or letter of offer in respect of an issue and to submit to SEBI a due diligence certificate confirming that disclosures made in the draft prospectus are true, fair and adequate to enable the investor to make a well informed decision. The lead manager will continue to be associated with the issue till the subscribers have received the share or excess application money.

Merchant banker either directly or indirectly prohibited from entering into any transaction in securities on the basis of unpublished price sensitive information. Merchant banker is required to inform SEBI within 15 days from the date of entering such transactions. SEBI may ask merchant banker any time to disclose his

$>$ Responsibilities of management of the issue

$>$ Change in the information furnished

$>$ Name of the companies whose issue he has managed

$>$ Breach of capital adequacy, and

$>$ His activities as a manger; consultant, underwrite to an issue.

SEBI may inspect books of account, documents and records of merchant banker either by giving reasonable notice or without notice in the interest of investors. SEBI is empowered to suspend a registration of a merchant banker in case he furnishes wrong or false information; fails to resolve the complaints of investors etc. In case of deliberate manipulation of price rigging or concerning activities or deterioration in the financial position, the board may also cancel registration of the merchant banker.

In the month of September 1997, SEBI abolished all categories of merchant bankers except Category-I. Category II, III and IV was allowed to continue till the end of their present term and after that they will have to apply for the category I license or status or take up some other activity. For example, they can register themselves for under taking activities like portfolio managers or under writes. Those merchant bankers who are undertaking activities like issue management, underwriting and portfolio management will be required to get registered as portfolio managers while underwriting could be done without any additional registration. As a result of such scheme number of merchant bankers declined. 
Earlier there was no difference between merchant bankers and NBFC's. Both were permitted to undertake fund based and non-fund based activities. Merchant bankers are being supervised by the SEBI and the NBFCs are being supervised by RBI. As a result the role of merchant bankers and NBFCs got differentiated. Merchant bankers are supposed to undertake as per SEBI directives only non fund based activities and NBFCs are supposed to undertake only fund based activities. Merchant bankers no longer accept demands, do lending and bill discounting or carry out fund based activities other than those related exclusively to the capital market.

The non fund activities which the merchant banker is supposed to undertake are:

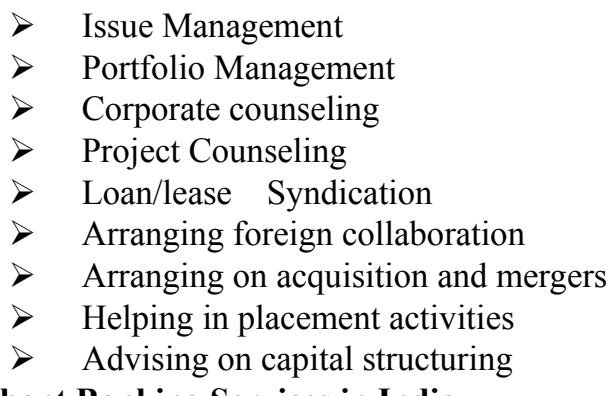

\section{Merchant Banking Services in India}

\subsection{ICICI Merchant Services}

ICICI Bank- India's largest private sector bank, and First Data, a global leader in electronic commerce and payment services, have formed a merchant acquiring alliance named ICICI Merchant Services which has acquired ICICI Bank's merchant acquiring portfolio. The venture brings together one of India's largest merchant portfolios, representing approximately 30 per cent of the current Indian acquiring market, and a leading acquirer and payment services provider with global expertise. Over time ICICI Merchant Services expects to deliver an enhanced suite of card acquiring services to existing and to new merchants.

ICICI Bank is India's second largest bank with over 2,000 branches across the country. First Data, a KKR company, provides payment processing services for 5.3 million merchant locations globally and serves customers in 36 countries around the world. First Data's services include offering merchants the ability to view and interrogate their payment transactions securely via the internet while benefiting from loyalty, prepaid and market-leading e-commerce solutions based upon advanced processing technologies.

\subsubsection{About ICICI Bank}

ICICI Bank Ltd (NYSE:IBN) is India's largest private sector bank and the second largest bank in the country with consolidated total assets of about US\$ 102 billion as of September 30, 2009. The ICICI Group has leadership positions across the financial services sector, including insurance, securities brokerage, asset management and private equity.

\subsubsection{About First Data}

First Data, a KKR company, powers the global economy by making it easy, fast and secure for people and businesses to buy goods and services using virtually any form of electronic payment. Whether the choice of payment is a gift card, a credit or debit card or a check, First Data securely processes the transaction and harnesses the power of the data to deliver intelligence and insight for millions of merchant locations and thousands of card issuers in 36 countries.

\subsection{PNB Merchant Banking}

Punjab National Bank-India's one of the Leading Nationalized Bank established in 1895 serving over 3.5 crores customers through 4520 branches and 439 extension counters, is the largest amongst Nationalized Banks. The Bank has recently been ranked $21^{\text {st }}$ among top 500 companies and $9^{\text {th }}$ among top 50 brands by The Economic Times. All the Branches of the Bank have been computerized. The Bank has adopted a concept of "Any Time, Any Where Banking" through the introduction of Centralized Banking Solution (CBS) and over 2511 offices have already been brought under its ambit.

The Bank is registered with SEBI as Category - I Merchant Banker for providing all the major Merchant Banking services. Its gamut of Merchant Banking services includes:

$>$ Issue Management Services - to act as Book Running Lead Manager/Lead Manager for the IPOs/FPOs/Right issues/Debt issues

$>$ Project appraisal 


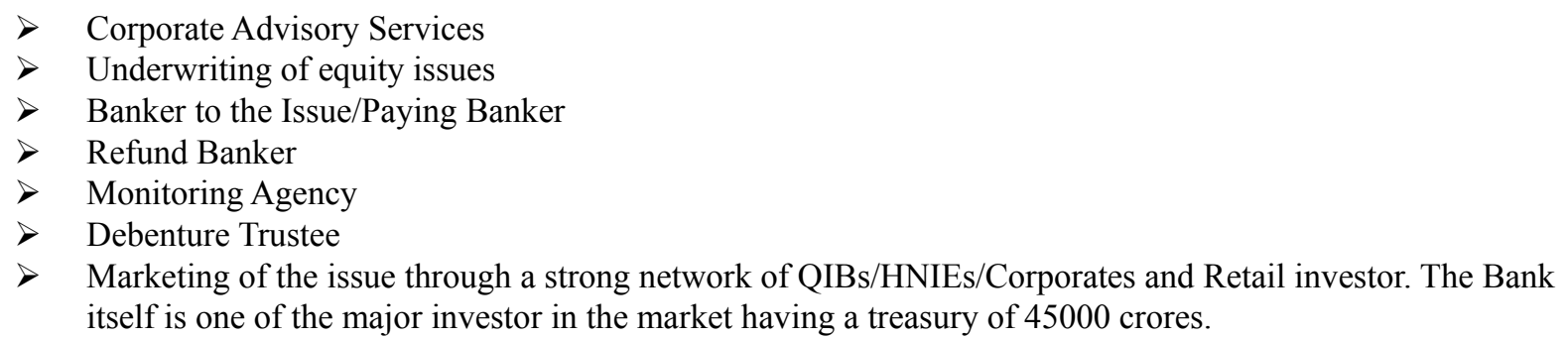

Its Software for handling the Refund Banker is one of the best systems in the industry. Its unique features provides online payment of the instrument by our 2470 branches in 733 centers, online status of paid instruments, cent per cent reconciliation at any point of time etc. The Bank has an exclusive and specialized Capital Market Service Branch at New Delhi for providing Merchant Banking Services to the Corporate.

\subsubsection{Depository Services}

Bank offers Depository Services to its clients and has designated large network of branches to cater to their demat requirements through Depository Participant of NSDL and CDSL depositories. Bank also provides the Speed -e facility to demat account holders to submit their delivery instructions through Internet. The Bank has recently launched "online securities trading facility" in strategic alliance with IDBI Capital Market Services Ltd.

\subsection{OBC Merchant Banking Division}

Oriental Bank of Commerce is registered with Securities and Exchange Board of India, as Category - 1 Merchant Banker since March 1, 1993. The Merchant Banking Activities are undertaken by its Merchant Banking Division housed in a separate premise at F-14, 4th Floor, Competent House, Connaught Place, New Delhi. The Merchant Banking Division is headed by a top Executive of the rank of General Manager with a dedicated team of officials having sufficient exposure and experience in this line. The Bank offers complete range of activities of category - 1 Merchant Banker as under:

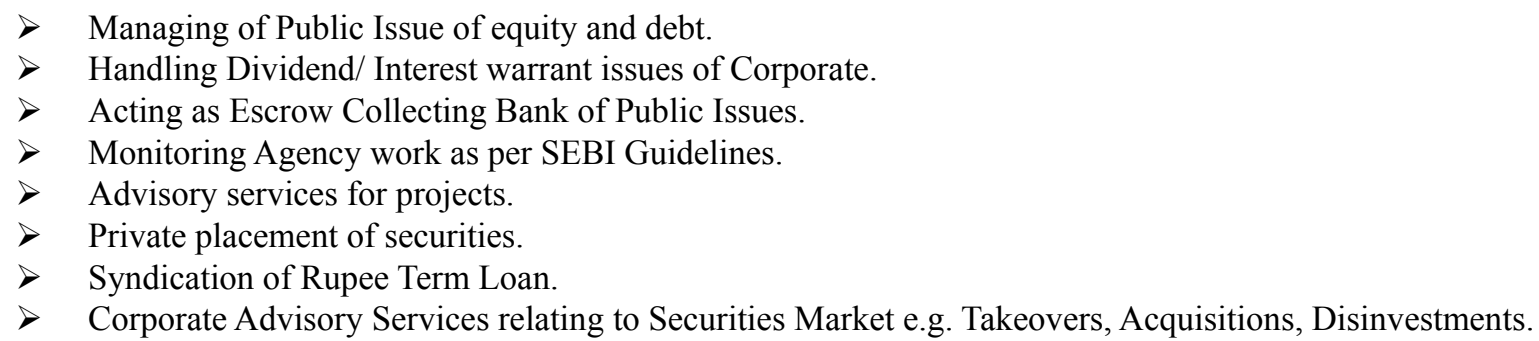

The Bank had made Initial Public Offer of 60 Million equity shares of Rs. 10/- each for cash at a premium of Rs. 50/per share in October 1994. Further, the Bank had made Follow-on Public Offer of 58 Million Equity Shares of Rs. 10/each for cash at a premium of Rs. 240/- per share aggregating Rs. 14500 Million in April 2005. As a result, the paid up equity share capital has gone up to Rs. 2505.397 Million and the Government of India's stake in the share capital of the Bank has come down to 51.09 per cent from 66.48 per cent.

The equity shares of the Bank are under compulsory dematerialization and 246.18 Million shares have been dematerialized as on 31st March 2010. The Bank has a large investor base of 1, 11,132 shareholders as on 31st March 2010. The broad shareholding pattern of the Bank as on $31^{\text {st }}$ march 2010 is: Government of India at 51.09 per cent; LIC, GIC and subsidiaries at 20.83 per cent; Domestic FIs, MFs and banks at 5.38 per cent; FIIs and NRIs at 15.19 per cent and Indian public and corporate at 7.51 per cent.

The Merchant Banking Division deals with all types of shareholders complaints and grievances as well as other related enquiries in connection with transfer of shares issued by the Bank. M/s.MCS Limited, Delhi has been appointed the Share Transfer Agent of the Bank for the purpose of dealing with the Shareholders in various matters viz., updation of change of address, non-receipt of dividend warrant, share certificate etc. The shareholders may approach directly either this Division or the Share Transfer Agent for all types of services relating to equity shares of the Bank.

\subsection{CANARA Bank Merchant Division}

Canara Bank is also one of the leading Merchant Bankers in India, offering specialized services to Banks, PSUs, State owned Corporations, Local Statutory bodies and Corporate sector. It was SEBI registered Category I Merchant Banker to render Issue Management (Public / Rights / Private Placement Issues), Underwriting, Consultancy and Corporate 
Advisory Services etc. It also hold SEBI registration Certificate to act as "Bankers to an Issue" with network of exclusive Capital Market Service Branches and over 100 designated CBS Branches to handle collecting / Refund / Paying Banker assignments. It does undertake "project appraisals" with linkage to resource raising plans from Capital Market / Debt Markets and facilitate tie-ups with Banks / Financial Institutions and Potential Investors. Its uniqueness is extending services under single window concept covering the following areas:

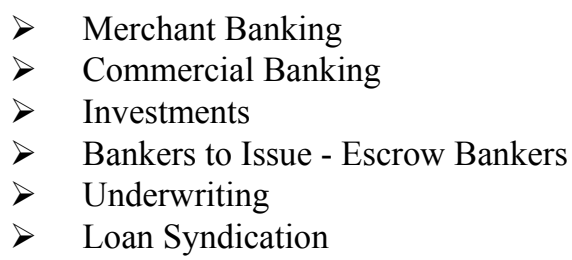

As leading Merchant Bankers in India, it has associated with issues ranging from Rs.1 crores to Rs.1500 crores, involving various types of industries, banks, statutory bodies etc. and has an edge in handling Private Placement issues both retail and HNIs.

\subsubsection{Spectrum of Services}

$>$ Equity Issue (Public/Rights) Management

$>$ Debt Issue Management

$>$ Private Placements

$>$ Project Appraisals

$>$ Monitoring Agency Assignments

$>$ IPO Funding

$>$ Security Trustee Services

$>$ Agriculture Consultancy Services

$>$ Corporate Advisory Services

$>$ Mergers and Acquisitions

$>$ Buy Back Assignments

$>$ Share Valuations

$>$ Syndication

$>$ ESOS Certification

4.3.2Issue Management Services

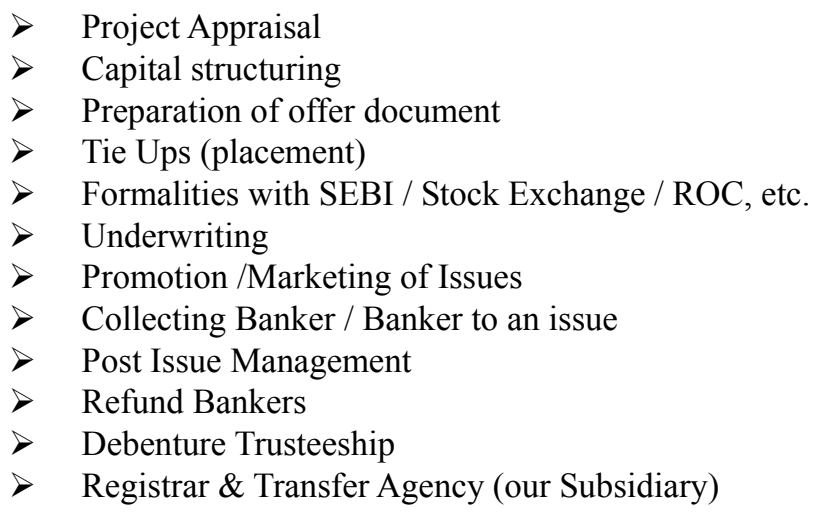

Bank constantly update the list of Potential Investors - Institutions, Provident, Pension and Gratuity Funds, High Net worth Individuals and others and continuously assess their investment appetites and help issuers in effective marketing of the products.

\subsection{ASBA Facility}

An application supported by blocked amount (ASBA) is an initiative by SEBI to make the process of Subscription to Capital Issues (Primary) more efficient. Under this system, the application money will remain in the account of the customer, till the allotment of shares. This facility has been provided to Savings Bank and Current Account holders who are eligible to apply as per SEBI guidelines, intending to invest in Capital issues (both Public and Rights issues). A Hold is created in the account of the customer to the extent of shares applied for and the same is released after the Allotment. The blocked amount is transferred to the issuer company to match the quantum of shares allotted. The 
following are the requirements for applying through the ASBA process by our Bank's Account holder:

$>$ Account holder/ Investor should be from the approved category eligible to apply as per SEBI guidelines.

$>$ Should have a Savings or Current account with us.

$>$ Should have a Demat account with a Depository Participant

$>$ Should have a Permanent Account Number ( PAN )

$>$ Availability of sufficient balance in the account for creating a hold in the account to the extent of application money required/mentioned in the ASBA application.

The following options are available to the ASBA investor:

$>$ A maximum of 5 applications can be submitted from a single account.

$>$ ASBA Application can be submitted at any of our six designated branches at present.

$>$ Option available to the investor to revise the bid/cancel the bid within the bidding period. Amount will be released only after clearance from the Registrar/Stock Exchanges.

\subsection{SBI'S Merchant Banking}

SBI's Merchant Banking Group is strongly positioned to offer perfect financial solutions to your business. SBI specialize in the arrangement of various forms of Foreign Currency Credits for Corporates and provide the resources, convenience and services to meet your needs by arranging Foreign Currency credits through:

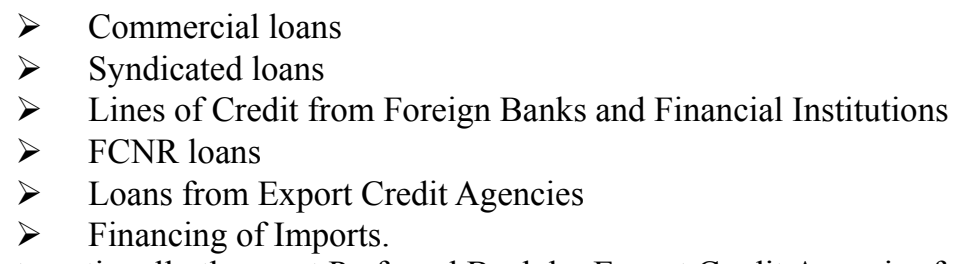

SBI is internationally the most Preferred Bank by Export Credit Agencies for Guarantees in case of the Indian Clients or Projects. SBI being an Indian entity has no India exposure ceiling. Its primary focus is on Indian Clients. SBI's seasoned Team of professionals provides Insightful credit Information and helps Maximize the Value from the transaction.

3.6.1Products and Services:

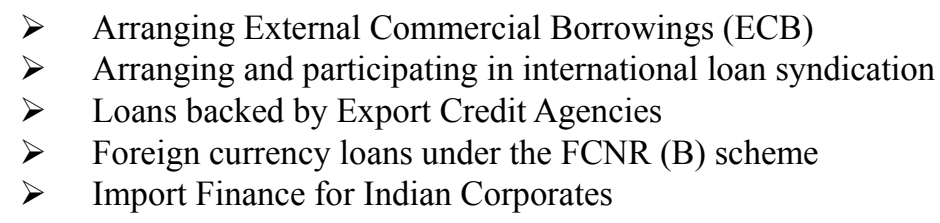

On 1st July State Bank of India was constituted under the State Bank of India Act 1955, for the purpose of taking over the undertaking and business of the Imperial Bank of India. The Imperial Bank of India was founded in 1921 under the Imperial Bank of India Act 1920. The Bank transacts general banking business of every description including, foreign exchange, merchant banking and mutual funds. On September State Bank of India (Subsidiary Bank) Act was passed. On October State Bank of Hyderabad become the first subsidiary of SBI.

During this period, State Bank of Jaipur, State Bank of Bikaner, State Bank of Indore, State Bank of Travancore, State Bank of Mysore, State Bank Patiala and State Bank of Saurashtra became subsidiaries of the bank. The Bhor State Bank Ltd was Amalgamated with the Bank bring the total number of minor State associated banks so amalgamated to five. A scheme for amalgamation of the Bank of Aundh Ltd., was also approved. On 20th August, the Unit Bank Ltd. Chennai was taken over by the Bank. In October Branch in London become bankers to the Indian High Commission, thereby taking over a function till then performed by the office of RBI. Of the other business transacted by the Branch, an important aspect was medium term loans mostly to Indian shipping companies. On November 8th the Bank of Behar Ltd was amalgamated. In 1972 A merchant banking division was set up in the central office to cater to promotional needs of the corporate sector.

During the year, company set up a data bank of sick units available for taken over by healthy units. With effect from 26th August, 1985 the Bank of Cochin Ltd with 108 branches was also amalgamated with the Bank.

(i) All shares in the Capital of the Imperial Bank of India were vested in the RBI. The SBI was registered with an Authorized capital of Rs.20 crores, and an issued and paid up capital of Rs.562, 50,000 divided into 562,500 shares of Rs. 100 each. 
(ii) Every person who on the 30th June, 1955, was registered as a holder of shares in the Imperial Bank of India was paid by the Reserve Bank of India.

On 1st August a new subsidiary named SBI Capital Market was functioning independently, took up leasing business and certain other new services. 100, 00, 00 No. of shares issued at a prem. of Rs 160 per share. SBICAP, in their capacity as Trustee and Manager of Mutual Fund, launched two scheme viz., Mangnum Monthly Income Scheme 1989 and Magnum Tax Service Scheme 1990. During the same period SBI in association with Morgan Stanley Asset Management Inc. of USA, launched the India Magnum Fund. In a significant move in 2001 the State Bank of India decided to distance itself from its subsidiaries - SBI Capital Markets, SBI Gilts, SBI AMC and State Bank of Credit and Commerce International. They will have the autonomy, independent chairmen and external executives at the senior management level at market-related salaries.

\section{Banker's Views on PSBs Merchant Banking}

Following results were derived from the administration of the questionnaire on 150 bankers regarding merchant banking business of PSBs. Majority of the PSBs are rendering merchant banking services relating to management of capital issue. Some leading banks are also taking the assignment of merger and acquisition of undertaking. In response to the first question reported in Table1, administrative staff of PSBs of the sample was in favour of more offensive marketing strategies for merchant banking business in order to compete with other merchant banking organizations.

The most of the innovative financial services of PSBs were started during the current decade, hence at nascent stage. World Bank also feels that the Indian Banking system still remain a massively inefficient, state controlled system and not competitive. Some questions were framed in the questionnaire to know the views of the administrative staff of PSBs regarding improvement of in the financial services of PSBs. The outcomes of the questions relating to the improvement of financial services of PSBs administered on 150 officials of various PSBs officers including office and head office of PNB has been discussed as the following paras.

Second question reported in Table 1 is based on the suggestion of the World Bank to reduce the government stake to 33 per cent in PSBs. In response to the question 86 per cent of the respondents expressed their view in positive as they believe that it will automatically reduce the degree of unfair political interference in the functioning of PSBs whereas 10 per cent of the respondents gave their response in negative.

Responses to third question regarding merger of PSBs revealed that 92 per cent of the PSBs officials of the sample strongly favoured the view of merger in order to grow quickly and reduce cost of operations etc. Only 8 per cent were not in favour of the merger. In response to the fourth question given in Table cent per cent of the PSBs officials covered by the sample were unanimously of the view that existing legal system is insufficient for tackling the financial services of PSBs and favoured for reform in the legal system of financial services of PSBs.

In response to question regarding frequent changes in the guidelines of regulatory authority, 56 per cent of the bankers covered in the sample responded in 'Yes' as they believe that frequent changes in the guidelines create confusion and restrict growths of financial services of PSBs. On the other hand, 36 per cent of the samples were in favour of frequent changes giving the reason that financial services particularly innovative financial services are at the nascent stage for which such changes are necessary according to the requirements of time and circumstances.

In response to question regarding multi regulatory authorities, 35 per cent of the administrative staff covered in the sample was of the view that present multi regulatory authorities system for various financial services of PSBs is appropriate where as 40 per cent of the officials against the multi regulatory authority.

Acquiring retaining and developing a competent staff is one of the impotent factors behind the success of any organization. At present the personal of the PSBs is recruited and selected by the Banking Services recruitment board and promotion of the staff is based upon seniority cum performance. 92 per cent of the respondent was in favour of promotion based on performance by PSBs itself; 86 per cent of the respondents were in favour of promotion based upon performance rather on seniority for efficient functioning of PSBs. On the other hand 14 per cent of the respondent favoured the existing promotion policy based on seniority cum performance as this does not leads to frustration of senior staff.

Generally it has been found that the senior officials handling traditional financial services of PSBs is assigned the task of managing and marketing of innovative financial services of PSBs. The third question of the table is concerned with the practice. 78 per cent of respondent answered in 'Yes' to the question. They believe that it is a matter of aptitude. A person doing well one work will also perform the other work well. Whereas 22 per cent of the respondents respond against the practice of giving reason that each service especially innovative financial services requires special skill, knowledge and experience and only attitude is not sufficient for marketing of innovative financial services. 
Furthermore, 80 per cent of the bankers expressed their view that each PSBs should enter into innovative financial services business but in the beginning starting may be done with one or two financial services. 16 per cent of the respondents were of the view that PSBs should venture into innovative financial services according to their weakness, strength and prevailing economic conditions. In response to the question regarding focus of marketing of financial services in rural and semi urban areas 82 per cent of the bankers were of the view that these areas should be covered with more emphases while marketing of innovative financial services as these areas are not covered by the private and foreign banks.

\section{Problems and Prospects of PSBs}

Analysis of merchant banking business of some PSBs including PNB and its subsidiary PNB CAP reveals that there is decline in the volume of PSBs merchant banking business. During early nineties there was a boom in the merchant banking business of PSBs but the boom could not survive for longer period and it converted into depression. It has been largely due to subdued capital market conditions as merchant banking activities has direct positive correlation with stock exchange index. Frequent changes in the guidelines also have been affecting the growth of PSBs merchant banking business. Limited range of merchant banking activities handed by PSBs and inferior quality of the services in compassion to lending private sector merchant bankers and foreign merchant bankers is also responsible for the depression in merchant banking services of PSBs. In PSBs largely the officials handling the traditional financial services have been engaged in the merchant banking activities whereas banking services requires expert services requiring specially skill, knowledge and training. Reforms are a continuous process; the progress made so far provides a good basis for merchant banking services. SEBI has formulated comprehensive guidelines for the growth of merchant banking activities. Many new entrepreneurs have been emerging which need assistance and expert advice of merchant bankers. PSBs have to develop the necessary skill and equip themselves to compete in the area of merchant banking. Product development is one of the weak areas of the PSBs. No attempt has been made to introduce non fund based products. This has to be tackled if the banks are to survive in a competitive environment.

\section{Concluding Remarks}

Merchant banking services strengthen the economic development of a country as they acts as sources of funds and information for corporations. Considering the way the Indian economy is growing, the role of merchant banking services in India is indispensable. These financial institutes also act as corporate advisory bodies to help corporations rightly get involved in various financial activities. The need of merchant banking services in India arises from the fact that high level industrialization is taking place in the country. There is need for skilled professionals who can take care of various finance-related needs of the advanced industrial sectors. These specialist services are also of great importance for the small and medium sized enterprises to help them operate smoothly. Most of the rural areas still lack industrial advancement and the main reasons for this include lack of funds and information. The merchant banking services help the entrepreneurs to come up with industrial setups in these areas. Besides, the merchant banks help the entrepreneurs to explore the joint venture opportunities in the foreign markets. Competition due to financial liberalization has compelled PSBs to diversify their non fund based activities e.g. lead managing co managing, underwriting advising loan syndicating capital issue management trusteeship etc. Non funded based financial services marketed by PSBs comes under purview of merchant banking which is governed by Merchant Bankers Regulation issued by SEBI of December 22, 1992. The regulation of the SEBI Act provided for registration of merchant bankers with SEBI for doing merchant banking.

Most of the PSBs including PNB have been doing merchant banking business. Some of the PSBs have formed their fully owned subsidiaries for this purpose. The activities being undertaken by most of the banks are lead managing co-managing, underwriting as a banker to issue etc. PNB was actively involved in merchant baking business such as underwriting, banker to issues, and payment of dividend/interest refund as and agent and trustee of debenture holders. PNB incorporated PNB capital Service Ltd as its wholly owned subsidiary. The company is registered with SEBI as merchant banker of category I and debenture trustee. Analysis of merchant banking business of some PSBs clearly indicates that the merchant banking activities of the banks are showing declining trend especially after 1993-94 due to depressed capital market conditions and subdued activity in primary market. 


\section{References}

Abd Ali Issa, (1997) Commercial Banks and Economic Development, Prueger Publisher, New York.

Agarwal A.N., (1999) Indian Economy: Problems of Development and Planning.

Avadhani V.A. (1999) Marketing of Financial Services, Himalaya Publication, Mumbai.

Allen, Franklin and Douglas Gale, (2000). Comparing Financial Systems (The MIT Press).

Basu C.R. (1991) Commercial Banking in the Planned Economy of India, Mittal Publication.

Bhatia B.S., Batra G.S., (1996) Management of Financial Services, Deep \& Deep Publication, New Delhi-27.

Bhole I, M., (1999) Financial Institution and Markets-Structures, Growth and Innovation, Tata Mc Graw Hills Publishing Co. Ltd.

Barth, James, Gerard Caprio and Ross Levine, (2001). "Banking systems around the globe: do regulation and ownership affect performance and stability"? in Frederic Mishkin, ed., Prudential Regulation and Supervision: Why it is Important and What are the Issues (Cambridge, Mass., National Bureau of Economic Research).

Caprio, Gerald and Maria Soledad Martinez-Peria, (2000). “Avoiding Disaster: Policies to Reduce the Risk of Banking Crises", Discussion Paper, Egyptian Center for Economic Studies, Egypt.

Claessens, Stijn, Asli, Demirgüç-Kunt and Harry Huizinga, (2000). "How Does Foreign Entry Affect The Domestic Banking Market"? in Claessens and Jansen, eds., The Internationalization of Financial Services: Issues and Lessons for Developing Countries (Dordrecht, Holland, Kluwer).

Clarke, George R.G. and Robert Cull, (1998). "Why Privatize: The Case of Argentina's Public Provincial Banks", Policy Research Working Paper No. 1,972, World Bank.

Clarke, George R.G. Robert Cull, Laura D'Amato and Andrea Molinari, (2000). “The Effect of Foreign Entry on Argentina's Domestic Banking Sector", in Claessens and Jansen, eds., The Internationalization of Financial Services: Issues and Lessons for Developing Countries (Dordrecht, Holland, Kluwer).

Deb, Kalipada, (1988) Indian Banking since Independence, Ashish publication House, New Delhi.

Desai, Vasant, (1997) Indian Financial System, Bombay, Himalaya Pub.

Demirgüç-Kunt, Asli and Enrica Detragiache, (1998). “Financial Liberalization and Financial Fragility”, Annual Bank Conference on Development Economics, Washington, D.C.

Demirgüç-Kunt, Asli and Harry Huizinga, (1997). "Determinants of Commercial Bank Interest Margins and Profitability: Some International Evidence”, World Bank Policy Research Working Paper No. 1,900.

Demirgüç-Kunt, Asli and Vojislav Maksimovic, (1998). “Law, Finance, and Firm Growth”, Journal of Finance, vol. 53, No. 6, pp. 2,107-2,137.

Doyle E P, (1981) Practice of Banking; Macdonald and Evans Ltd., USA.

Farhat Husain, (1986) Public Sector Commercial Banking in India, Deep \& Deep Publishers, New Delhi.

Gilson, Stuart, Kose John and Larry Lang, (1990). “Troubled Debt Restructurings: An Empirical Study of Private Reorganization of Firms in Default”, Journal of Financial Economics, vol. 27, pp. 315-353.

Government of India, Economic Survey, Various annual issues, Ministry of Finance, New Delhi

Government of India, (1972) Report of the Banking Commission, New Delhi.

Government of India, (1993) Economic Reforms- Two Years and Task Ahead, Ministry of Finance, New Delhi.

Hanson D.G., (1979) Service Banking-A Commentary on Bank Service in the U.K., Institute of Bankers, London.

Hoshi, Takeo, Anil Kashyap and David Scharfstein, (1990). "The Role of Banks in Reducing the Costs of Financial Distress in Japan", Journal of Financial Economics, vol. 27, pp. 67-88.

International Monetary Fund (IMF), (2001). “India: Recent Economic Developments and Selected Issues”, IMF Country Report No. 01/181.

Jayaratne, J. and P.E. Strahan, (1996). "The Finance-Growth Nexus: Evidence from Bank Branch Deregulation", Quarterly Journal of Economics, vol. 111, pp. 639-670.

Joshi, Vijay and I.M.D. Little, (1996). India's Economic Reforms: 1991-2001 (Oxford, Clarendon Press). 
Juan-Ramon, V. Hugo, Ruby Randall and Oral Williams, (2001). "A Statistical Analysis of Banking Performance in the Eastern Caribbean Currency Union In The 1990s", Working Paper WP/01/105, International Monetary Fund.

Jam B.M., (1997) Impact of Financial Liberalization Policy in India, Mumbai, Himalaya Publishing House.

Khan M.Y., (1997) Financial Services, Tata Mc Graw Hill Publishing Company Ltd. New Delhi.

Khan M.Y., (1996) Indian Financial System; Tata Mc Graw Hill Publishing Company Ltd., New Delhi.

Kotler Philip and Armstrong; Garg, (1999) Principles of Marketing, Prentice hall of India Ed-8.

King, Robert G. and Ross Levine, (1993), "Finance and Growth: Schumpeter Might Be Right", Quarterly Journal of Economics, August, Vol. 108, No. 3, pp. 713-737.

Levine, Ross, (1996). "Foreign Banks, Financial Development and Economic Growth", in Claude E. Barfield, ed., International Financial Markets (Washington, D.C., AEI Press).

Mathur B.L., (1986) Management of Financial Services. RBSA Publications. First Ed.

McKinnon, Ronald, (1973). Money and Capital in International Development ;Washington, D.C., Brookings Institution. Punjab National Bank, Annual Reports, Various Years, New Delhi

Ranga Swami B.,(1985) Public Sector Banking in India, Govt. of India, New Delhi 1985

Rao K. Srinivasa, (1983) Public Sector Banks Lending in India and the Productivity Question. Ashish Publishing House, New Delhi 1983.

RBI, Report on Currency and Finance, Various issues, Reserve Bank of India, Mumbai

RBI, Report of the Committee on Functioning of Public Sector Banks, Reserve Bank of India,

RBI, Trend and Progress of Banking in India, Various issues, Reserve Bank of India, Mumbai

RBI, Handbook of Indian Economy, Various issues, Reserve Bank of India, Mumbai

Sethi T.T., (1999) Money, Banking and International Trade, S. Chand \& Company Ltd., Delhi.

Singhal Sushila, (1987) Banks and Customers: A Behaviours Analysis, Sri Ram Centre, New Delhi.

Srinivasan R., (1995) Priority Sector Lending: A Study of Indian Experience Bombay. Himalaya Pub.

Subramanium K., (1997) Banking Reforms in India-Managing Change, Tata Mc Graw hills Publishing Company Ltd.

Suneja H.R., (1995) Innovation in Banking Services, Himalaya Publishing. Bombay.

Santos, Joao A.C., (1998). "Commercial Banks in the Securities Business: A Review”, Bank for International Settlements Working Papers No. 56.

Sarkar, Jayati, Subrata Sarkar and Sumon K. Bhaumik, (1998). "Does Ownership Always Matter? Evidence from The Indian Banking Industry", Journal of Comparative Economics, Vol. 26, pp. 262-281.

Sarkar, Jayati and Sumon Kumar Bhaumik, (1998). "Deregulation and the Limits to Banking Market Competition: Some Insights from India”, International Journal of Development Banking, July-December.

Stiglitz, Joseph and Andrew Weiss, (1981). "Credit Rationing in Markets with Imperfect Information", American Economic Review, Vol. 71(3), pp. 393-410.

Tondon Prakash, (1988). Banking Century-A Short History of Banking in India and the Pioneer: Punjab National Bank, Penguin Books, New Delhi.

Walter, Ingo and H. Peter Gray, (1983). "Protectionism and International Banking, Sectoral Efficiency, Competitive Structure and National Policy", Journal of Banking and Finance, Vol. 7, pp. 597-607, 609.

World Bank, (2001). Finance for Growth: Policy Choices in a Volatile World; New York, Oxford University Press.

Yoshitomi, Masaru and Sayuri Shirai, (2000). Technical Background Paper for Policy Recommendations for Preventing another Capital Account Crisis, Asian Development Bank Institute.

Yoshitomi, Masaru and Sayuri Shirai, (2001). Designing a Financial Market Structure in Post-Crisis Asia - How to Develop Corporate Bond Markets, Asian Development Bank Institute Working Paper No. 15. 
Table 1. Views of PSBs on Merchant Banking

\begin{tabular}{|c|c|c|c|}
\hline & \multicolumn{3}{|c|}{ (Figures in percentages) } \\
\hline Questions & Yes & No & Can not says \\
\hline \multicolumn{4}{|l|}{ Marketing Strategies Merchant Banking of PSBs } \\
\hline $\begin{array}{l}\text { 1. Do the PSBs need more offensive marketing strategies for Merchant banking } \\
\text { business at a time when many new Entrepreneur have been emerging which need } \\
\text { assistance and expert advice? }\end{array}$ & 80 & 20 & Nil \\
\hline \multicolumn{4}{|l|}{ Government Stake in PSBs and Their Merger } \\
\hline $\begin{array}{l}\text { 2. Should the stake of government in PSBs as called by the World Bank be not more } \\
\text { than } 33 \text { per cent for better management and growth of PSBs? }\end{array}$ & 86 & 10 & 4 \\
\hline $\begin{array}{l}\text { 3. Sould the PSBs also merged on the lines of merger taking place in banks in many } \\
\text { countries of the world for quick growth at national as well as at international level? }\end{array}$ & 92 & 8 & Nil \\
\hline \multicolumn{4}{|l|}{ Legal System and PSBs } \\
\hline $\begin{array}{l}\text { 4. Does the existing legal system comprehensively deals with the financial services of } \\
\text { PSBs? }\end{array}$ & Nil & 100 & Nil \\
\hline 5. Does the existing legal system relating to financial services of PSBs need reform? & 100 & Nil & Nil \\
\hline \multicolumn{4}{|l|}{ Regulatory System and PSBS } \\
\hline $\begin{array}{l}\text { 6. Do the frequent changes in the guidelines of financial Services of PSBs adversely } \\
\text { affect the growth of PSBs? }\end{array}$ & 56 & 36 & 8 \\
\hline $\begin{array}{l}\text { 7. Should financial of PSBs and of their subsidiary be regulated by one regulatory } \\
\text { authority (RBI) instead of multi regulatory Authorities? }\end{array}$ & 40 & 35 & 25 \\
\hline \multicolumn{4}{|l|}{ Personnel Policies of PSBS } \\
\hline 8. Should PSBs be given authority to select their suitable personnel? & 92 & 8 & Nil \\
\hline $\begin{array}{l}\text { 9. Should the promotion of PSBs official be based on performance rather than on } \\
\text { seniority in order to improve the performance of PSBs? }\end{array}$ & 86 & 14 & Nil \\
\hline $\begin{array}{l}\text { 10. Will a PSBs official performing well in managing and marketing of traditional } \\
\text { services of PSBs also necessary be performing well in managing and marketing of } \\
\text { innovative financial services? }\end{array}$ & 78 & 22 & Nil \\
\hline \multicolumn{4}{|l|}{ Marketing Strategies of PSBs } \\
\hline $\begin{array}{l}\text { 11. Should each PSBs venture into one or two innovative Financial services at first } \\
\text { instead of most of the innovative financial services at a time? }\end{array}$ & 80 & 16 & 4 \\
\hline $\begin{array}{l}\text { 12. Should PSBs pay proper attention to marketing of innovative financial services at } \\
\text { rule and semi urban areas also in order to reap the advantage of vas network of branch } \\
\text { as in these areas private sector banks are not a source of competition? }\end{array}$ & 82 & 16 & 2 \\
\hline
\end{tabular}

Merchant Banking Servces

Merchant Eanker

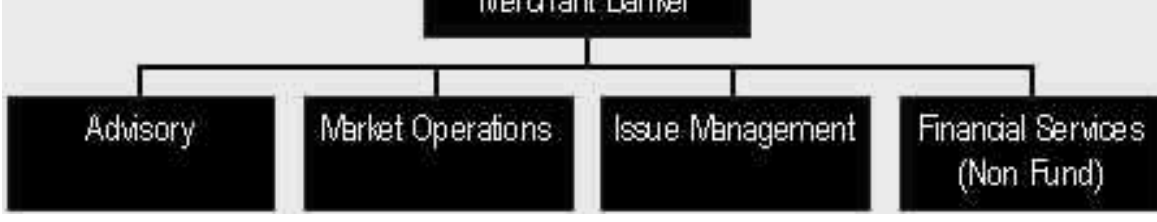

Figure 1. Merchant Banking Services 